\title{
Martyr Burial Philosophy from the Viewpoint of Imam Khomeini and Imamieh Jurisprudence
}

Sajad Rhimikia, Yoones Nikandish ${ }^{*}$

Department of Jurisprudence and Law, Yasooj Branch, Islamic Azad University Yasooj, Iran

*Corresponding author: Yoones Nikandish, Department of Jurisprudence and Law, Yasooj Branch, Islamic Azad University Yasooj, Iran, Tel: +98 21 4486 5179; Email: unes.nikandish2016@gmail.com

Received date: May 06, 2016; Accepted date: July 20, 2016; Published date: July 30, 2016

Copyright: (c) 2013 Nikandi Y, et al. This is an open-access article distributed under the terms of the Creative Commons Attribution License, which permits unrestricted use, distribution, and reproduction in any medium, provided the original author and source are credited.

\begin{abstract}
Being killed for the sake of religion, homeland, or political opinion is in different forms in different societies; but is commonly honored and praised. Thus, victims and even deprives and survivors of the war are respected in all nations, governments and the public. In Islamic culture, this kind of sacrificing for the sake of Allah is called "martydom".

Human fascination for martyrdom brings this question to mind that while many people fear from death what the difference is between this type of death and other deaths that it leads them to welcome death. In examining this issue, which is essentially what the distinction is between martydom and other deaths, referring to the Qur'an and Sunnah can be the best solution. Contemplating these two sources give various characteristics. In this thesis, the literal and technical concepts of martyr, equivalents of sacrificing and martyrdom in other religions, the concept of martyrdom in the Shiite school and the rules and virtues of burying martyr are studied. The obtained result is that martydom for the sake of Allah is a huge triumph that is not obtainable by all the people because martydom means welcoming death, which is obviously different from the other types of death, and it is with positive results such as eternal life with peace, joy and forgiveness of sins, the divine gift and the lack of need for bathing an enshrouding the deceased.
\end{abstract}

Keywords: Martyr; Martyrdom; Death; Bathing; Enshrouding; Burial

\section{Introduction}

Culture of martyrdom is a complex issue that those who adore glorious beauty of Allah have a longstanding dialog with him. This unlimited culture is the supreme and most sacred flame of improving humanity and the long-standing movement of history in developing and promotion of human society and different human generations.

Martydom, in the motifs of thought, realization of humanitarian ideals and oversights, human promotion strategies and its approaches in different areas of life, is the best song of entity and the distinguishing feature of the life of few people who sit to watch over the long human history.

Meanings that are placed in front of committed men is completed with martydom, and when one who goes this way becomes "martyer", he will always take residence on the apex of the eternal life of the universe.

Martydom is a kind of death of thought and knowing, and without it basically one does not call any death martyrdom.

For those who are in this side of the world, the world after the world here is the invisible world, but to those who come to the reality, the superior and the other world is the world of martyrdom, and our world is the invisible world.

One who did not exit from the web of self, he is not traveler and seeker to Allah and his death will not be testifying, but one whose intention is toward Allah and exited from the web of self, and he wants to come from invisible world to visibility of world and visiting the Allah, he is a martyer.

Culture of sacrifice, Basij militia, Hezbollah (Allah Followers), service, Sacred Defence, sacrifice are familiar terms used by the ulama, scholars, officials and managers in Iran, and sometimes on the basis them, they enact some regulations [1].

It is clear that we should search the origin and source of this culture in our Islamic religious belief and resources.

The culture of martyrdom is religious heritage and the unique result of the Islamic Revolution, which its teachings were presented and distributed by the great teacher and great leader of the Islamic Revolution- Imam Khomeini - who had done many efforts in deepening and stablizing them. Nowedays, the supreme leader Ayatollah Khamenei- emphasis on following, developing and extending of those cases. He regards Shahid as a combination of vision, action and sacrifice and believes that without these three elements, no complementary movement can occured, and humanity caravan do not step toward the summit of virtue and perfection - without observing this elements (Ibid: 53).

Martyrdom - this sublime and sacred state - is the result of human choice, specific vision and Special Attitude.

The culture of martyrdom compromises institutionalized, homogenous, balanced and coherent attitudes and behaviors that lead men to the great value of martyrdom. Thus, martyrdom is an immense and successful event for those who follow the ideals and values and by growing up in the sacrifice space, they think of a status and position 

Sajad Rhimikia, Yoones Nikandish

epartment of urisprudence and Law asooj ranch Islamic ad niversity asooj Iran

Corresponding author: oones ikandish, epartment of urisprudence and a, asoo ranch, slamic ad niversity asoo, ran, el ; mail unesnikandishgmailcom

Received date: ay , ; Accepted date: uly , ; Published date: uly ,

Copyright: ikandi, et al. his is an open-access article distributed under the terms of the reative ommons ttribution icense, hich permits unrestricted use, distribution, and reproduction in any medium, provided the original author and source are credited.

Abstract

eing killed for the sake of religion, homeland, or political opinion is in different forms in different societies; but is commonly honored and praised. hus, victims and even deprives and survivors of the ar are respected in all nations, governments and the public. $\mathrm{n}$ slamic culture, this kind of sacrificing for the sake of llah is called "martydom".

uman fascination for martyrdom brings this uestion to mind that hile many people fear from death hat the difference is bet een this type of death and other deaths that it leads them to elcome death. $\mathrm{n}$ e amining this issue, hich is essentially hat the distinction is bet een martydom and other deaths, referring to the ur an and unnah can be the best solution. ontemplating these $t o$ sources give various characteristics. $n$ this thesis, the literal and technical concepts of martyr, e uivalents of sacrificing and martyrdom in other religions, the concept of martyrdom in the hiite school and the rules and virtues of burying martyr are studied. he obtained result is that martydom for the sake of llah is a huge triumph that is not obtainable by all the people because martydom means elcoming death, hich is obviously different from the other types of death, and it is ith positive results such as eternal life ith peace, oy and forgiveness of sins, the divine gift and the lack of need for bathing an enshrouding the deceased.

Keywords: artyr artyrdom eath athing nshrouding urial

\section{Introduction} glorious beauty o Allah have a longstanding dialog with him unlimited culture is the supreme and most sacreadimproving humanity and the longstanding movement o history in develop and promotion o human society and human generations

artydom, in the motis o thought, realiation o humanitarian culture o martyrdom is religious heritage and the uniue result ideals and oversights, human promotion strategies and its appreshamic Revolution, which its teachings were presented an in areas 0 lie, is the best song 0 entity and thstributed by the great teacher and great leader 0 the slamic distinguishing eature $o$ the lie $o$ ew people who sit to watch Reblution mam Khomeini who had done many in the long human history

eanings that are placed in ront o committed men is completegtollah Khamenei emphasis on ollowing, developing and with martydom he will always take residence on the ape 0 the eternal lie oft universe

artydom is a kind o death o thought and knowing, and witheits elements bid:

it basically one does not call any death martyrdom

or those who are in this side o the world, the worlthe world choice,

artyrdom this sublime and sacred state is the result o human here is the invisible world, but to those who come to the reality, the superior and the other world is the world o martyrdom, and our world culture 0 martyrdom compromises institutionalied, is the invisible world

homogenous, balanced and coherent attitudes and behaviors that men to the great value o martyrdom martyrdom is an immense

ne who did not eit rom the web o sel, he is not traveler arahd successul event or those who ollow the ideals and values and seeker to Allah and his death will not be testiying, but one grborigg up in the space, they think o a status and position 
